\title{
LEARNING SPEAKING USING FLASH CARDBOARD: ENGLISH AS A FOREIGN LAnguage Students' PerCePtion
}

\author{
Siti Wulan Asih ${ }^{1)}$, Ida Rahmah Andansari ${ }^{2)}$, Ely Widayati ${ }^{3)}$, Didik Murwantono ${ }^{4)}$ \\ ${ }^{1)}$ Ahmad Dahlan University, Yogyakarta, Indonesia \\ E-mail: sitiwulanasih006@gmail.com \\ ${ }^{2)}$ Ahmad Dahlan University, Yogyakarta, Indonesia \\ E-mail: idarahmah202@gmail.com \\ ${ }^{3)}$ Ahmad Dahlan University, Yogyakarta, Indonesia \\ E-mail: ummunais84@gmail.com \\ ${ }^{4)}$ Sultan Agung Islamic University, Semarang, Indonesia \\ E-mail:didik.m@unissula.ac.id
}

\begin{abstract}
Flash cardboard is one of the media used for speaking, especially in storytelling. Teaching by using media is very necessary for learning because it greatly influences the results of the learning process. This research wants to know English as a Foreign Language (EFL) students' perception after they learned storytelling using flash cardboard as a media. This was phenomenological research. This research used semi-structured interviews with some students who used flash cardboard in learning storytelling. Purposive sampling was used in this research. The result shows that the student got positive impacts facilitated by the flash cardboard media, they became more confident in speaking in front of the class, they were not involved because flash cardboard helped them, students also supported speaking fluently, they can produce more than 190 words per minute (wpm) but not necessarily perfect command of intonation, vocabulary, and grammar. By using flash cardboard as the media, the media can be an alternative method in learning English specifically speaking class because it forces students to speak (really make them speak) following the target language. In the end, it can also be concluded that learning English using flash cardboard media can improve students' language skills and speaking skills. The students maintain their ability in speaking smoothly not necessarily perfect command of intonation, vocabulary, and of course the grammar. The recommendation for further study is the other researchers can add the respondents with another English skill.
\end{abstract}

Keywords: EFL Students' Perception; Flash Cardboard; Learning Speaking

\section{INTRODUCTION}

To teach English, the teacher must be creative in using learning media to enable the students to learn English better. The teacher must also be able to teach English. Media is an agent or message transmitted from the sender to the message recipient. More specifically, the notion that media is a means of capture, process and rearrange visual or verbal information appears to be defined as graphic, photographic or electronic instruments the learning media are tools or devices for processing that enable education and learning activities to be done by educators and learners.

The media thus acts as a tool, a means to communicate, execute or carry out a message or ideas to activate students' emotions, feelings, behavior, and desires so that teaching and learning processes take place in students. In learning media, the message or the content to be transmitted or the program comprises two elements, and (b) display computer or hardware. Many media are available that are important for the teaching process of learning like a flashcard. Flashcard for teaching English is an image jargon (or diagrams, 
phrases, etc.) that you can show students, usually something you can hold up when you're standing in front of the entire class. The photos are divided into different types on the flashcard: animals, fruit, color, form, alphabet, numbers, occupations, etc. (Muyaroah \& Fajartia, 2017; Widodo, 2018).

Media can be applied in teaching speaking. Because speaking is one of the skills which difficult to learn properly because the ultimate objective of a language is to be a tool for communication. Thus, the media needed to improve students'speaking. According to Leong and Ahmadi (2017) P.w, Said, and Waris (2015) defined that is of great importance for the interaction between people where they talk everywhere and every day.

Speaking is the way of communicating ideas and messages orally. If we want to encourage students to communicate in English, we should use the language in real communication and ask them to do the same process. Speak is the process of building and share meaning in some contexts by using verbal and nonpeak symbols. The ability is developed by many repetitions and is above all a neuromuscular process rather than an intellectual one. English as foreign language students or EFL students is often taught in speech. English as a Foreign Language is EFL. This curriculum allows students over 16 years to improve their English skills, in particular their master's skills.

EFL can be defined as an English study by persons living where English can not be used as a means of communication in the first language. He also states that in this environment the students have little chance of communicating outside the classroom with English. EFL applies to those who learn English in non-English-speaking countries. (e.g. Japanese people who learn English in their country are EFL learners). And in countries where English is used as a communication tool and is formally spoken (e.g. Latinos, learners of English, and ESL) the ESL refers to people learning English (Haines et al., 2013).

Effective or not a learning media in teaching speaking EFL students, it is necessary to have students 'perceptions of the media was used, the purpose of the students 'perceptions is to find out the extent of students' responses when learning activities using media. Perception is our method of recognizing the various stimuli that influence our senses. Witness affects the stimulus or the meaning that we receive and what we offer when we become conscious of it. The experience of the student is the process of sensing or comprehending sensory data. The term "perception" originates from the words perceptio, percipio in Latin, meaning "acceptance, gathering, taking over, and fear with the mind or senses" (Qiong, 2017). Perception can be seen as a mechanism in which stimuli are collected, arranged, and perceived in the context. As students learn how to speak, especially telling stories with flash cardboards, students perceive their stimuli when learning in class, naturally these activities influence students and so they should express their opinions. The aim is to enable the teacher to find the appropriate medium for teaching.
In many cases, almost all EFL students did not confident in learning speaking. Speaking English became the hardest lesson for EFL students, sometimes they have a limited idea for increasing their speaking. That case is the big problem that should be solved by the teacher. In Mts N 6 Bantul, Yogyakarta used flash cardboard as a medium for teaching speaking, especially in storytelling. Thus, the researcher curious and the ELF students' perception after they learned speaking by using flash cardboard media.

This research is supported by several studies that discuss students' perceptions about several things such as the research who did by Haines et al. (2013) about students' perceptions of the use of blogs in English language learning. The findings from the data analysis outline that the students perceive blogs as a beneficial application for English language learning in the areas of writing, reading, and communication. However, they also admit that challenges remain in authoring blogs, such as performance fluctuation, self-confidence, and aspects of technology.

Hidayati, Kharisma, and Satriani (2018) discussed students' perceptions in applying cooperative learning in the EFL classroom. The result of this research showed that the final year students of the Indonesian education study program of IKIP Siliwangi Bandung had positive responses toward the implementation of Cooperative Learning. Besides that, it was found that students familiar with group activities in the EFL classroom. To sum up, Cooperative Learning is a good approach for the students to learn English easily, although, Zadeh (2016) researched EFL Learners' attitudes and perceptions about an effective English language teacher. They obtained findings revealed that all of these components are important in effective teaching from EFL learners' point of view, including relational factors, environmental dynamic, and knowledge of the language, common standards, performance assessment, and classroom planning.

The research about students' perception of EFL speaking skill development did by Nazara (2011) the findings revealed that all respondents viewed speaking important and they were willing to deal with the necessities to master it. Although they got interesting materials, empowering activities, and proper opportunities to practice speaking, they insisted to have a longer time to practice. Besides, some respondents tended to avoid speaking due to their fear of lecturers' 'scolding' and classmates' laughing. EFL students' attitudes and perception towards English language learning and their English language proficiency: a study from Assa'adah Islamic Boarding School, Indonesia who did by Jaliyya and Idrus (2017) found that students have positive attitudes and were motivated to learn the language although learning the language might not stem from their willingness to.

Odeh (2016) researched students' perceptions of English language learning in the Facebook context. Findings revealed that EFL students believe that $\mathrm{FB}$ as an online learning environment facilitates, supports, and encourages their English language learning. Besides, the findings indicate that students' motivation and confidence in English language learning improved via FB. The study also revealed 
that students had a positive attitude towards this learning model. In light of the findings of the study, it is recommended that TEFL teachers should plan learning classes that use SNS such as Facebook as a learning platform.

EFL Students' perceptions towards using social media at Ajloun National University were the result of Salamah et al. (2018). This result highlighted the importance of those sites as effective sites used by the EFL learners in learning the English language efficiently in classroom communication. Moreover, the findings of this study revealed that there were no statistically significant differences between male and female students in their perceptions of using social media sites. Finally, the researchers recommended that it is useful to encourage students to use different activities and exercises available on social media sites as much as possible because they could improve the process of learning the English language.

Allam and Elyas (2016) researched the perception that EFL professors in the Saudi context use social media as an ELT tool. A review of the collected data revealed that most of the participants strongly believe in the pedagogical principles and advantages of using social media as an ELT resource in the Saudi classroom. Nevertheless, the majority expressed reservations about the scope of the free use of social media in the EFL classroom you consider the effect of the two edges of the sword to be mainly because of some unintended distractions some students may resort to, which can sometimes contribute to the opposite effect of their use. In this area the study suggests more research to understand carefully how experienced EFL teachers use social media within their classes to establish best practices for a social media application in EFL teaching and learning in the Saudi context.

The last is result by Nursanti (2016) who discussed students' perception of teacher's bilingual language use in an English classroom students show their positive perceptions of the use of bilingual language done by the teacher as language instruction in their English classroom; (2) there are six benefits of teacher's bilingual language use for students in learning English; making them easy to understand what the teacher explained in English lesson, feel comfortable during the class, easy to understand new vocabularies in English, help them to do exercises, help them to ask and answer something during the class, and help them to read something in English correctly.

This research wants to know the EFL students' perception after they using flash cardboard in learning storytelling. The previous research discussed EFL students' perception using the media and several methods in teaching English, but the previous research did not use flash cardboard as teaching media. Thus the writer does the same research but focuses on using flash cardboard especially in learning storytelling.

\section{Methodology}

This research used a phenomenological qualitative research design supported by a semi-structured interview. It was a qualitative research methodology that focused on the shared experience of a specific group and the perception of the phenomenon based on the interpretation of their own experiences (Husserl, 1980). The purpose of phenomenology is to understand how one or more individuals experience a phenomenon and to examine their terms, explanations, thoughts, and interpretation of the phenomenon from the participants in detail (Moustakas, 1994; Patton, 1990). While the sampling was taken by purposive sampling to choose students who have learned storytelling using flash cardboard media. The participant in this research involved one of MTs N 6 Bantul students in class 8th. Taking this sample based on Dornyei's (2007) time and resource limitations prevented me from reaching the ideal number of participants 6-10, data collection was taken through direct interviews with students.

\section{RESULTS AND DISCUSSION}

This section describes the research questions concerning the student's perception of using flash cardboard as a media in teaching speaking. It also discusses the findings in terms of relevant literature. Some of the student's statements in the interview are quoted verbatim to support the explanation of the findings.

Perception generally consists of observation of a certain situation or environment. It can be a mental image, concept, or awareness of the environment's elements through physical sensation or physical sensation interpreted in the light of experience and captivity for comprehension. This general definition can be understood as someone's ability to see, to hear, to feel, and to present or to understand what they feel about their environment their social life physically, and mentally.

\section{A. Speaking}

The student is conscious that speaking is one of the most important skills as a means of effective communication to be learned and improved. She also feels that speaking ability is considered one of language learning's most difficult aspects. She senses that it is difficult for many language learners to express themselves in the spoken language. Generally speaking, they face problems using the foreign language to effectively express their thoughts. Harmer (2007) stated speaking is the ability to speak fluently and presupposes not only knowledge of language features, but also the ability to process information and language "on the spot"e. Troudi and Nunan (1995) wrote that generally there are two types of spoken language, as follow:

a. Monologue

Brown states that monologue is the speaking where one speaker uses spoken languages for any length of time, such as in speeches, lectures, readings, news broadcasts, and the like, then the listener has to process the information without interruption and the speech will go on whether or not the listeners comprehend what the speaker means.

b. Dialogue

It is different from monologue; Nunan says that dialogue is the speaking that involves two or more speakers. The interruption may happen in the speech 
when the interlocutor does not comprehend what the speaker says. According to Harmer (2007) Finally, we should make a difference between speaking, which is scheduled (for example, speaking or weeding), and speech unplanned (for example, speaking spontaneously).

This skill that must be mastered is speaking. This is a core skill because from speaking we will know whether someone knows a language or not. Speaking for most people is considered the most difficult skill because it covers many aspects of English including pronunciation, listening, grammar, and vocabulary as well. But all that is needed is a little courage and great motivation to be able to speak English fluently.

In this paper, speaking is conducted in form of a monologue, which also tried to have dialog in monologue. In a monologue in the form of storytelling, Najma conducts a monologue as well as a dialogue. Because in storytelling there is a discussion in which the characters speak with one another. Then Najma also conducts dialogue by showing his expertise in terms of differences in voice between characters.

Najma tried to learn the language in a friendly way that allows her to speak it. She builds her hearings in the process for what sounds good. As a result, she finally learns how to speak the language like this, whether it sounds right to them or not. This way can closely resemble that of the learning of the first language.

\section{B. Flash Cardboard}

One of the items that can be seen is the Flashcard. There are three types of educational media, namely audio (technical media that are difficult to use like radios or cassette recorders), visual media (technical media that are visible) which can be heard and seen such as video and television).

Flash cardboard is made from used cardboard. Then it is cut in a rectangular shape. The pictures are browsed from the internet then printed on white paper. In the paper, there are keywords to guide the student in running speaking. The paper contains pictures and words then adhered to the cardboard. The size is about A4 as paper.

This article describes the statement from the student in Islamic Junior High School about the comments in using flash cardboard as a media in speaking in form of a monologue. English subjects applied in curriculum 2013 which involved students to be more active in learning English. Najma commented that using the flash cardboard supported much to explain the story.

"Using flash cardboard, I feel easier to speak. It is because there is a picture that is suitable for the story. It also makes me more understand in expressing the narrative text. The media is really helpful in smoothing spoken text".

Picture in the cardboard is one of the media that can be looked at and include as the visual media, in particular, is considered as an effective means to support learning since students learn most through the sense of sight (Chee \&
Wong, 2003). She also added that “...the picture in the media can trigger the mind. It would help to elaborate the object of the story".

Using pictures will aid the student to help to produce utterances. Pictures are always interesting to everyone, especially beginners and children (Paulsom et al., 1992: 2). Picture series are used as tools for the preparation of narrative texts by students. Not only any series of images are the pictures used. Several requirements are available for the researchers ' use of image sequence s. The photos taken will hit the learning goals first of all. The content of the photographs should be adapted to the needs of the student. Above all, the photos are clear, understandable, and certainly interesting so that photos as media are truly effective

\section{Self-Confident}

The willingness of students to learn English as a foreign language (EFL) is usually low, as well as limited exposure to English speakers or members of the international community (Zhang, 2009). This could be one explanation for why teachers provide students with more conditions and experiences to improve their speaking skills. Furthermore, Najma said:

"If I use media like that, it's like... I'm more confident because someone is holding media and playing it while telling a story. Ehm...I was not nervous, flash cardboard helps reduce the feeling of awkward in public".

One type of learning media is images or photos. Through the media images or photos can help children to know things that are known to children or unknown to children. In connection with this in this study using media in the form of images in which the media image is one of the types of visual media that represents the original form (people, objects, animals, plants, and surrounding objects). By using picture media, it is hoped that learning can provide a pleasant, cheerful atmosphere and can foster activity and creativity in early childhood learning.

In the term of media, she never used such as media in speaking before. In learning English, she and the other students are facilitated mostly by textbooks and exercising books made by the local teacher association. Sometimes she thinks that reading is a boring activity, especially reading a book whose contents are all written without any pictures, it's better to watch TV or YouTube will be more fun and enjoy. She added that:

"I feel good using flash cardboard media. I will...will...be calmer in speaking because there is a definite grip so that speech becomes directed and the possibility of mistakes will be reduced".

\section{Story Telling}

Storytelling can help to establish and maintain a supportive and interactive classroom community. Such to Linse and Nunan (2005), there are many important reasons for telling stories to children of all ages as well as supporting them to tell their own. According to Harmer (2007: 38), kids enjoy discovering things and teachers need to provide 
perspectives of learning from different sources. In this case, Michaels (1991: 288) discusses three methods for teaching children; 1) vivid photos (sketches, cuts of magazines, etc.), 2) stories providing pure language, and 3) games as time-out of play.

In light of the theory, Najma assumed that speaking is very important in learning English, although is not included in the national examination. Speaking is very closely related to who is spoken to. In telling a story, for example, the storyteller or story conveyor must understand the contents of the story that is conveyed so that the positive messages contained in the story are conveyed properly. So the speaker needs to hold on to the story to be told, in this case, is the media.

"If you already use a flash cardboard, the communication between the storyteller and the audience will be well established, uhm ... the same understanding between the speaker and the audience ... this will be fun, because it looks like the chat it that ..continue".

At the beginning of the storytelling activity, Najma, who is now in class VIII MTsN 6 Bantul, was looking for texts suitable for teenagers in general. After that, the woman read it over and over 10 or 20 times. And at that time he tried hard to memorize the text. In the fifteenth rote, the teacher suggested using pictures as a reference in telling the story. Najma finally practiced using pictures as a medium. The indicators of fluency that has been constructed cover the speed (rate of speech), semantic density (fillers), and hesitation (pauses). Sometimes they use fillers to tell their stories, it's endorsed by the English teacher who said some students still use fillers like "emm," "uh," "yak" twice until only four times. The instructor said it's natural because they're still at the elementary student level. When you look for the best way to express your thoughts, she may use her speaker.

Furthermore, in carrying out storytelling, she also uses flash cardboard that is facilitated by the teacher accompanying her.

"I like finding something new ... like finding a certainty to convey the story smoothly without disturbance ... stopping... because I forgot ... uh ... interrupted his words... and I will be ashamed of the jury or other friends and teacher".

The core activity is storytelling. The storyteller will tell the story by paying attention to words, body gestures, and sound games so that they display visual images in the minds of children as audiences. To attract the interests of children in the storytelling process, it is necessary to have properties such as small dolls that are used in the hands to represent figures that are becoming fairy tale material. The other props that can be used include dolls, puppets, cloth, pictures, or by drawing directly. Storytelling by using props can make the story feel more interesting because children can immediately see the visual form of the story being told.

Burling in Bruner (1986) stated fluency develops in storytelling. Apprentices learn the language in a friendly way that allows them to speak it. They build their hearings in the process for what sounds good. As a result, they learn how to speak a language like this, whether it sounds right to them or not. This process closely resembles that of the acquisition of a first language.

According to Pyo (cited in Richard et al., 1985), the average speech rate of an elementary school is $130 \mathrm{wpm}$, which is considerably slower than the natural speed of native speakers (about160 to $190 \mathrm{wpm}$ ). Concerning this, Najma is Islamic Junior high school that can produce more than 190 wpm.

When they search for the correct manner to say their words, they may use fillers such as „,uhm', ,emm' and have a silent pause or silent period in $1-3$ seconds. Fitrianingsih (2017) constructed the concept of ,think time', defined as a distinct period of uninterrupted silence by the teacher and all students so that they both can complete appropriately information processing tasks, feelings, oral responses, and actions.

\section{E. Challenge for EFL students}

In general, the EFL students are sometimes seemed confronted by the silent situation in the language classroom and the low level of motivation. This condition became a challenge for EFL teachers to overcome such a problem. The perception of children as speakers of foreign languages in learning to speak becomes important to be used as a learning experience. Najma is a student who is relatively positive in learning English so that when there are questions or competitions related to English, he welcomes the challenge.

"When I have to speak English...I....I am afraid of being mistake. I ashamed making mispronunciation, actually I want to be fluently in speaking English. But sometime' my colleague said me mockingly. They say "sokinggris".

The teacher has the role to motivate the learner to improve their knowledge of English subjects as well as their behavior. So the student can produce spoken language to communicate the ideas easily but not necessarily perfect command of intonation, vocabulary, and of course the grammar.

\section{CONCLUSIONS AND SUGGESTIONS}

Considering the findings and discussion, it is clear that the participant perceives that using flash cardboard as a medium to learn speaking would help to improve selfconfidence. It also supported speaking fluently. She can produce more than 190 words per minute (wpm) but not necessarily perfect command of intonation, vocabulary, and grammar. By using flash cardboard as the media can be an alternative method in learning English specifically speaking class because it forces students to speak (really make them speak) following the target language. In the end, it can also be concluded that learning English using flash cardboard media can improve students' language skills and speaking skills.

It is necessary to develop images on game cardboards that are adapted to the learning theme. It would be better if the game media were also adjusted to the language glossary 
(English for Specific Purposes). The use of flash cardboard will force students to 'talk' according to the learning context, so it is better to practice speaking so that they become accustomed to the conversation. Perform simulations properly and correctly according to the teacher's instructions.

\section{ACKNOWLEDGMENT}

We would like to thank Causal Productions for permits to use and revise the template provided by Causal Productions. The original version of this template was provided by courtesy of Causal Productions (www.causalproductions.com).

\section{REFERENCES}

Allam, M., \& Elyas, T. (2016). Perceptions of Using Social Media as an ELT Tool among EFL Teachers in the Saudi Context. English Language Teaching, 9(7), 1. https://doi.org/10.5539/elt.v9n7p1

Bruner, J. S., \& Austin, G. A. (1986). A study of thinking. Transaction publishers.

Chee, T.S., and Wong, A.F.L. (2003). Teaching and learning with technology: An Asia -Pacific perspective. Prentice-Hall: Pearson Education Asia.

Dörnyei, Z. (2007). Creating a motivating classroom environment. In International handbook of English language teaching (pp. 719-731). Springer, Boston, MA.

Fitrianingsih, A. (2017). A study on pair work and storytelling for teaching speaking fluency. Jurnal Pendidikan Edutama, 4(1), 1-8.

G. Jaliyya, F., \& Idrus, F. (2017). EFL Students' Attitudes and Perception towards English Language Learning and Their English Language Proficiency: A Study from Assa'adah Islamic Boarding School, Indonesia. Journal of Education and Learning (EduLearn), 11(3), 219. https://doi.org/10.11591/edulearn.v11i1.4621

Haines et al. (2013). Students' Perception of the Use of Blog in English Language Learning. Journal of Chemical Information and Modeling, 53(9), 1689-1699. https://doi.org/10.1017/CBO9781107415324.004

Harmer, J. (n.d.). (2007). Jeremy Harmer-How to Teach English-Pearson ELT.

Herlina, H., \& Dewi, R. R. (2017). Flashcardboard Media: the Media for Developing Students Understanding for English Vocabulary At Elementary School. Ijer - Indonesian Journal of Educational Review, 4(1), 116. https://doi.org/10.21009/ijer.04.01.11

Hidayati, L. A., Kharisma, I., \& Satriani, I. (2018). Students' Perception in Applying Cooperative Learning in EFL Classroom. ETERNAL (English, Teaching, Learning and Research Journal), 4(1), 16-30. https://doi.org/10.24252/eternal.v41.2018.a2

Hotimah, E. (2010). Penggunaan Media Flashcardboard Dalam Meningkatkan Kemampuan Siswa Pada Pembelajaran Kosakata Bahasa Inggris. Jurnal Pendidikan Universitas Garut, 4(1), 10-18.
Retrieved from www.journal.uniga.ac.id

Husserl, E., \& Gibson, W. R. B. (1980). Ideas: general introduction to pure phenomenology. New York: Collier Books.

Leong, L.-M., \& Ahmadi, S. M. (2017). An Analysis of Factors Influencing Learners' English Speaking Skill. International Journal of Research in English Education, 2(1), 34-41. https://doi.org/10.18869/acadpub.ijree.2.1.34

Linse, C. T., \& Nunan, D. (2005). Practical English language teaching: young learners/by Caroline $T$. Linse; David Nunan, series editor. New York: McGraw-Hill/Contemporary.

Michaels, J. R. (1999). Risking Intensity: Reading and Writing Poetry with High School Students. National Council of Teachers of English, 1111 W. Kenyon Road, Urbana, IL 61801-1096 (Stock No. 417140015: \$11.95 members, \$15.95 nonmembers)..

Moustakas, C. (1994). Phenomenological research methods. Sage publications.

Muyaroah, S., \& Fajartia, M. (2017). Pengembangan Media Pembelajaran Berbasis Android dengan menggunakan Aplikasi Adobe Flash CS 6 pada Mata Pelajaran Biologi. Innovative Journal of Curriculum and Educational Technology, 6(2), 2226.

Nazara, S. (2011). Students' Perception on EFL Speaking Skill Development. JET (Journal of English Teaching), $1(1), \quad 28$. https://doi.org/10.33541/jet.v1i1.50

Odeh, A. (2016). Students' perceptions of english language learning in the facebook context Students Perceptions of English Language Learning in the Facebook Context by Atef Odeh abusa aleek. Researchgate Publication, 4(November 2015), 15.

Poulsom, R., Pignatelli, M., Stetler-Stevenson, W. G., Liotta, L. A., Wright, P. A., Jeffery, R. E., ... \& Stamp, G. W. (1992). Stromal expression of $72 \mathrm{kda}$ type IV collagenase (MMP-2) and TIMP-2 mRNAs in colorectal neoplasia. The American journal of pathology, 141(2), 389.

P.w, R., Said, M. M., \& Waris, A. (2015). Developing Speaking Skill of Grade Viii Students Through Short Conversation. English Language Teaching Society (ELTS), 3(1), 1-13. Retrieved from https://media.neliti.com/media/publications/244500 -none-65dd45e8.pdf

Qiong, O. U. (2017). A Brief Introduction to Perception. Studies in Literature and Language, 15(4), 18-28. https://doi.org/10.3968/10055

Richards, P. (1985). Indigenous agricultural revolution: ecology and food production in West Africa.

Salamah, N. B., Abu-dames, A., Al-zaareer, H., \& Sobh, M. A. Al. (2018). EFL Students Perceptions towards Using Social Media at Ajloun National University. $5(5), 1-12$.

Troudi, S., \& Nunan, D. (1995). Research Methods in Language Learning. TESOL Quarterly, 29(3), 601. 
https://doi.org/10.2307/3588081

Widodo, S. A. (2018). Selection of Learning Media Mathematics for Junior School Students. Turkish Online Journal of Educational Technology - TOJET, 17(1), 154-160.

Zadeh, R. F. (2016). EFL Learners' Attitudes and
Perceptions about an Effective English Language Teacher. 3(2), 148-156.

Zhang, Q. M. (2009). Affecting factors of native-like pronunciation: A literature review. Korea Education \& Research Institute, 27(2), 33-52. 